\title{
Safety of $\mathrm{N}$-Acetylcysteine at High Doses in Chronic Respiratory Diseases: A Review
}

\author{
Peter Calverley ${ }^{1} \cdot$ Paola Rogliani $^{2} \cdot$ Alberto Papi $^{3}$
}

Accepted: 13 November 2020 / Published online: 16 December 2020

(c) The Author(s) 2020

\begin{abstract}
$\mathrm{N}$-Acetylcysteine (NAC) is widely used in respiratory medicine, with a maximum licensed dose in chronic use of $600 \mathrm{mg} / \mathrm{day}$; however, some clinical trials have studied the efficacy of NAC at higher doses. The aim of this review was to evaluate the adverse effects profile of NAC at higher than the standard dose in chronic respiratory diseases to establish a risk-benefit ratio in increasing the daily dose; therefore, studies using NAC at a dose of at least $600 \mathrm{mg} / \mathrm{day}$ were selected. Forty-one articles where NAC has been used at $600 \mathrm{mg}$ and above, up to $3000 \mathrm{mg} /$ day, and with a specific report on safety, were considered. Most of the studies used oral NAC and were conducted on patients with chronic obstructive pulmonary disease, idiopathic pulmonary fibrosis, bronchiectasis, chronic bronchitis and cystic fibrosis. In general, the safety profile was similar at both the high and standard doses with the oral formulation; gastrointestinal symptoms were reported but they were no more common than in the control group.
\end{abstract}

\section{Key Points}

$N$-Acetylcysteine (NAC) has several indications and can be used in respiratory medicine [chronic obstructive pulmonary disease (COPD), interstitial lung diseases such as idiopathic pulmonary fibrosis (IPF), bronchiectasis, and influenza], and has been used worldwide for over 50 years.

When treatment requires chronic use, as in COPD and cystic fibrosis, the maximum licensed dose is $600 \mathrm{mg}$ / day, but doses $>600 \mathrm{mg}$ daily have been studied in some clinical trials.

Studies of high doses of NAC (up to $3000 \mathrm{mg} /$ day) in respiratory diseases with explicit reports on safety found that NAC was safe and well tolerated. In general, the safety profile is similar at both the high and standard doses.

\section{Alberto Papi}

ppa@unife.it

1 School of Aging and Chronic Disease, University of Liverpool, Liverpool, UK

2 Department of Experimental Medicine, University of Rome "Tor Vergata", Rome, Italy

3 Section of Cardiorespiratory and Internal Medicine, Department of Medical Sciences, Research Centre on Asthma and COPD, University of Ferrara, Ferrara, Italy

\section{Introduction}

$N$-Acetylcysteine (NAC) has been used worldwide for over 50 years. It has several indications and can be used in respiratory medicine [chronic obstructive pulmonary disease (COPD), interstitial lung diseases such as idiopathic pulmonary fibrosis (IPF), bronchiectasis, and influenza], as an antidote for paracetamol poisoning, and in contrastinduced nephropathy (CIN), psychiatric and neurological illnesses, and addictive behaviours [1-6].

NAC administered intravenously at a total dose of 300 $\mathrm{mg} / \mathrm{kg}$ can be safely used to prevent liver necrosis in cases of paracetamol (acetaminophen) poisoning [6, 7]. It has also been safely used at high doses to limit CIN [2, 3, 8-10]). In both situations, high doses of NAC are administrated for a relatively brief period.

When treatment requires chronic use, as in respiratory diseases, the maximum licensed dose is $600 \mathrm{mg} /$ day, usually administered once daily. The main indication for chronic use has been COPD, which is characterized by chronic symptoms in patients with airflow obstruction as a result of exposure to inhaled noxious agents, and sometimes as a result of additional abnormalities in lung development [11]. It is often accompanied by exacerbations of the disease symptoms. NAC has also been used on a regular basis in patients with cystic fibrosis (CF), which is characterized by severe bronchiectasis and tenacious sputum, and in patients with IPF subtypes, predominantly interstitial pneumonia, which leads to chronic, progressive 
fibrosis, a progressive decline in lung function and respiratory failure [12].

The optimal dose for effective treatment has not been determined and doses $>600 \mathrm{mg}$ daily have been studied in some clinical trials. To properly evaluate the cost benefit of NAC treatment, we need to understand the adverse effect profile of the drug and whether it changes with higher doses. This is the focus of the current manuscript.

\section{Methods}

Literature searches of the PubMed database (with no date limitations) were conducted in December 2019 and January 2020 using the search terms ' $N$-acetylcysteine', 'NAC', 'respiratory tract infection', 'cystic fibrosis', 'COPD', 'bronchitis' and 'idiopathic pulmonary fibrosis' in titles and abstracts, and restricting the results primarily to articles written in English. The focus of this review was the safety of NAC at high doses in chronic respiratory diseases, therefore studies using NAC at a dose of at least 600 $\mathrm{mg} /$ day were selected. Articles not explicitly reporting on safety in either the full text or the supplementary materials were excluded. The authors examined the resulting lists of articles and excluded those that did not mention data on safety. Studies on patients not affected by chronic respiratory diseases were excluded. Using these criteria, a total of 41 articles were identified and are considered in this review.

\section{Results and Discussion}

Studies are presented as daily NAC doses according to the pathology; oral formulations are the most commonly used. High doses administered orally have been studied in trials involving COPD, IPF and CF. Other formulations (intravenous and inhaled) are considered separately because they do not have the same issues in terms of safety (Table 1).

\subsection{N-Acetylcysteine (NAC) $600 \mathrm{mg} /$ day}

There is a lot of evidence on oral NAC at the $600 \mathrm{mg} /$ day dose because this is the maximum amount approved to date in most countries.

\subsubsection{Chronic Bronchitis}

The definition of chronic bronchitis used in these studies varied, with the most common being cough and sputum production for at least 3 months in 2 consecutive years without any indication for airflow obstruction. In a systemic review,
Stey et al. [13] focused on the effects of NAC in chronic bronchitis. Eleven randomized controlled studies (published between 1976 and 1994) totalling 2540 patients randomized to NAC or placebo were considered in that study. Data on 2011 patients (996 receiving oral NAC 400-600 mg/day and 1015 receiving placebo) were analysed to evaluate the efficacy of NAC on exacerbation. Overall, $10.2 \%$ of patients treated with NAC reported dyspepsia, diarrhoea or heartburn during the study period, compared with $10.9 \%$ of patients in the control group, leading the authors to conclude that NAC was no more harmful than placebo in the treatment of chronic bronchitis.

Similarly, Grandjean et al. [14] performed a meta-analysis of published double-blind, placebo-controlled clinical trials on chronic bronchitis, which included trials from 1980 to 1995 where NAC was administered orally at a daily dose from $400 \mathrm{mg}$ (one study, 203 patients enrolled) to $1200 \mathrm{mg}$ (one study, 129 patients enrolled); most studies reported on NAC $600 \mathrm{mg}$ (a total of 1076 patients enrolled). The minimum duration of treatment was 3-6 months (seven studies). The efficacy analysis showed that a prolonged course of oral NAC prevented acute exacerbations and, in terms of safety, that oral treatment with NAC was well tolerated. Adverse effects were usually mild, mostly gastrointestinal, and did not require treatment interruption. There were no significant differences between the treated and placebo groups in terms of adverse events.

Some of the studies in the two review articles reported above may overlap because they analysed the same topic in a similar time span, but, despite this limitation, the data suggest that NAC $600 \mathrm{mg} /$ day is well tolerated in these patients over extended periods of treatment.

\subsubsection{Chronic Obstructive Pulmonary Disease (COPD)}

An open, randomized, parallel group, controlled study conducted in Italy by Pela et al. [15] and lasting 6 months evaluated 169 patients with moderate to severe COPD. Eightyfour patients continued their standard therapy ( $\beta 2$-agonists, anticholinergics, theophylline, inhaled and/or oral corticosteroids) and 80 added NAC $600 \mathrm{mg}$ once daily to their standard therapy. At the end of the study, three of six patients in the NAC group experienced adverse effects, reporting gastric complaints (two patients) and diarrhoea (one patient); one patient dropped out of the study because of severe adverse events. Gastric complaints were also reported by one patient in the standard therapy group; one patient had loss of appetite and one patient had pyrosis. The total dropout rate was two patients in the NAC group and four patients in the standard therapy group. The authors observed that NAC 600 $\mathrm{mg}$ /day was well tolerated, and the oral formulation likely improves compliance with the treatment. 


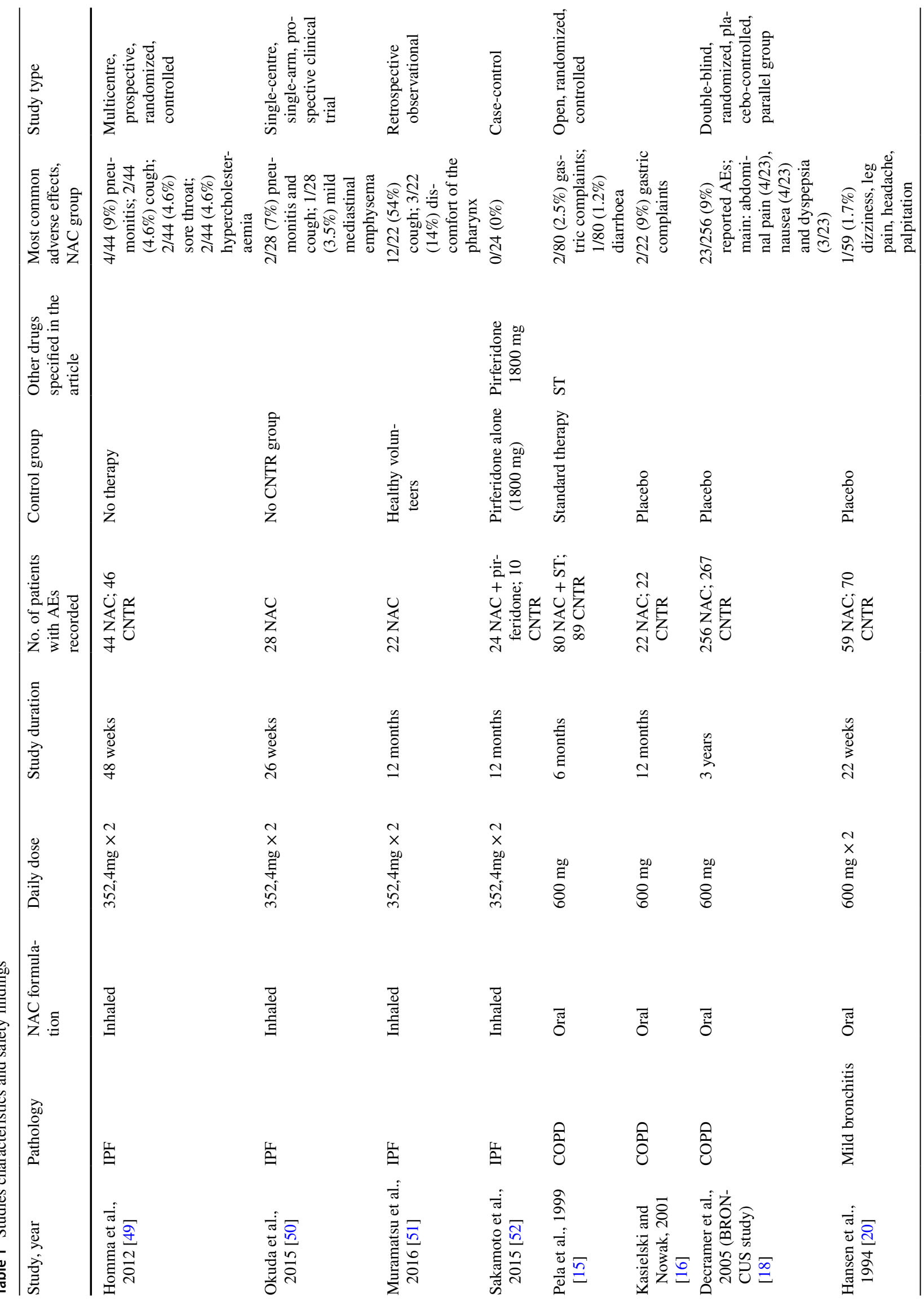




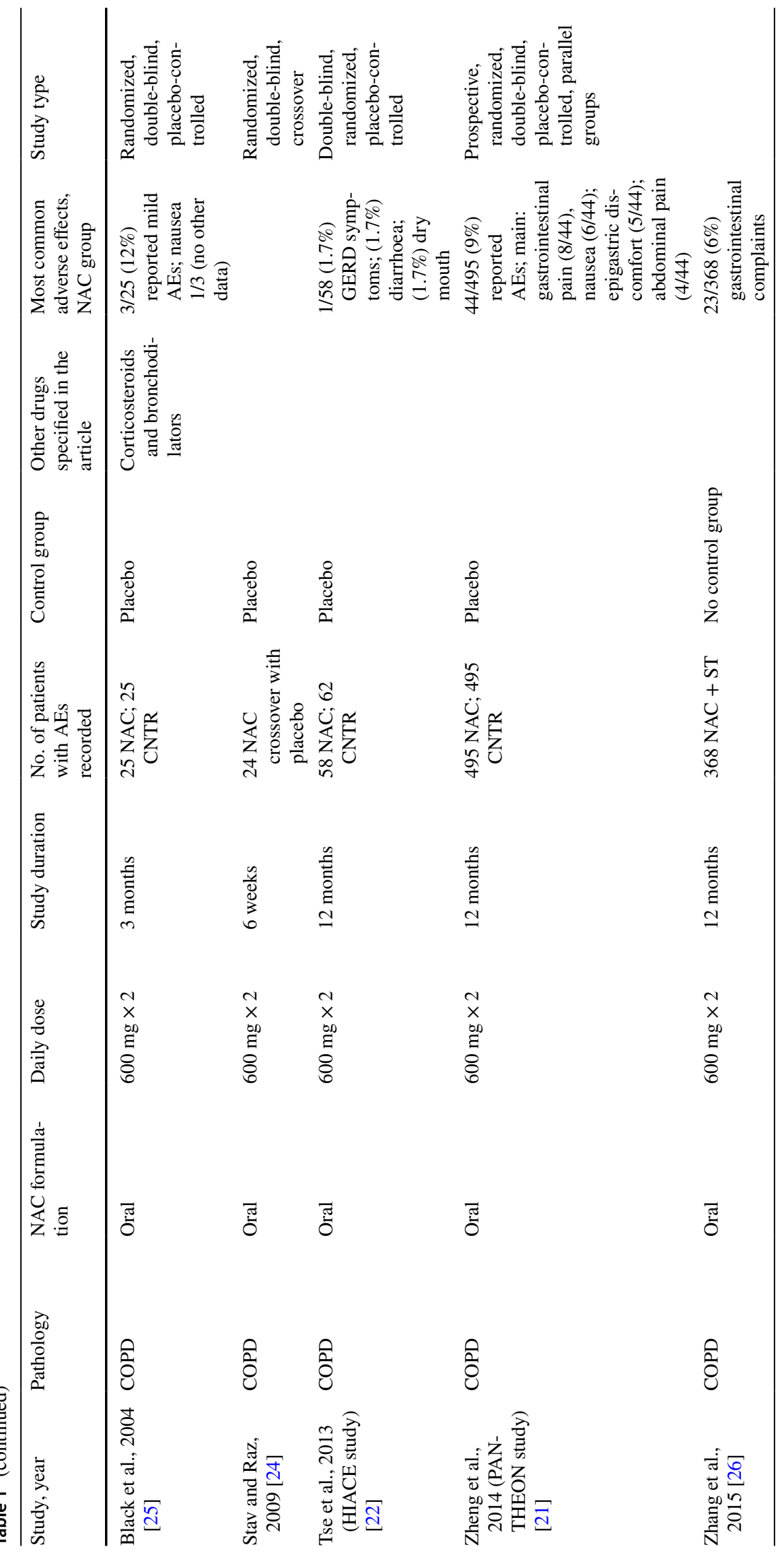




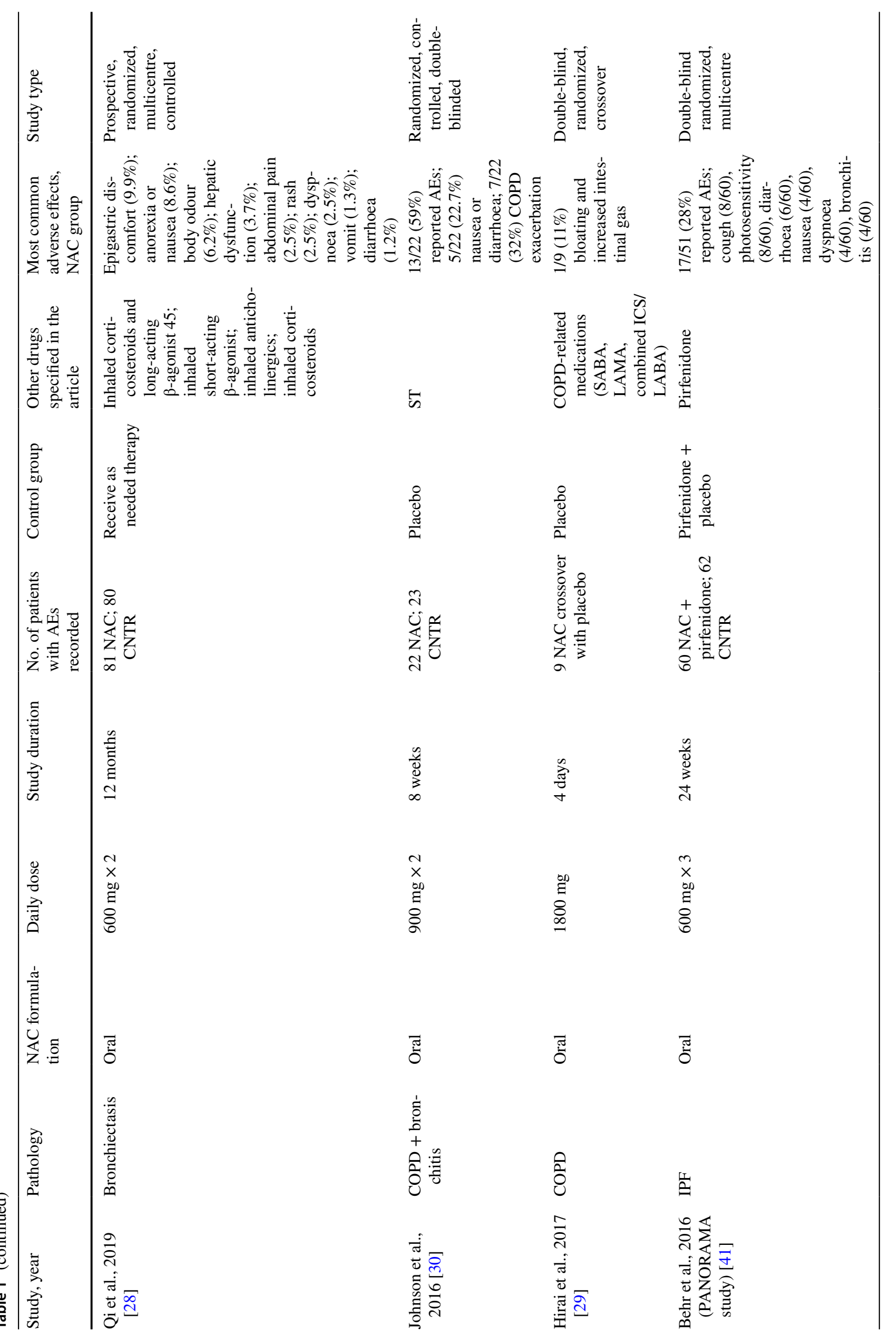




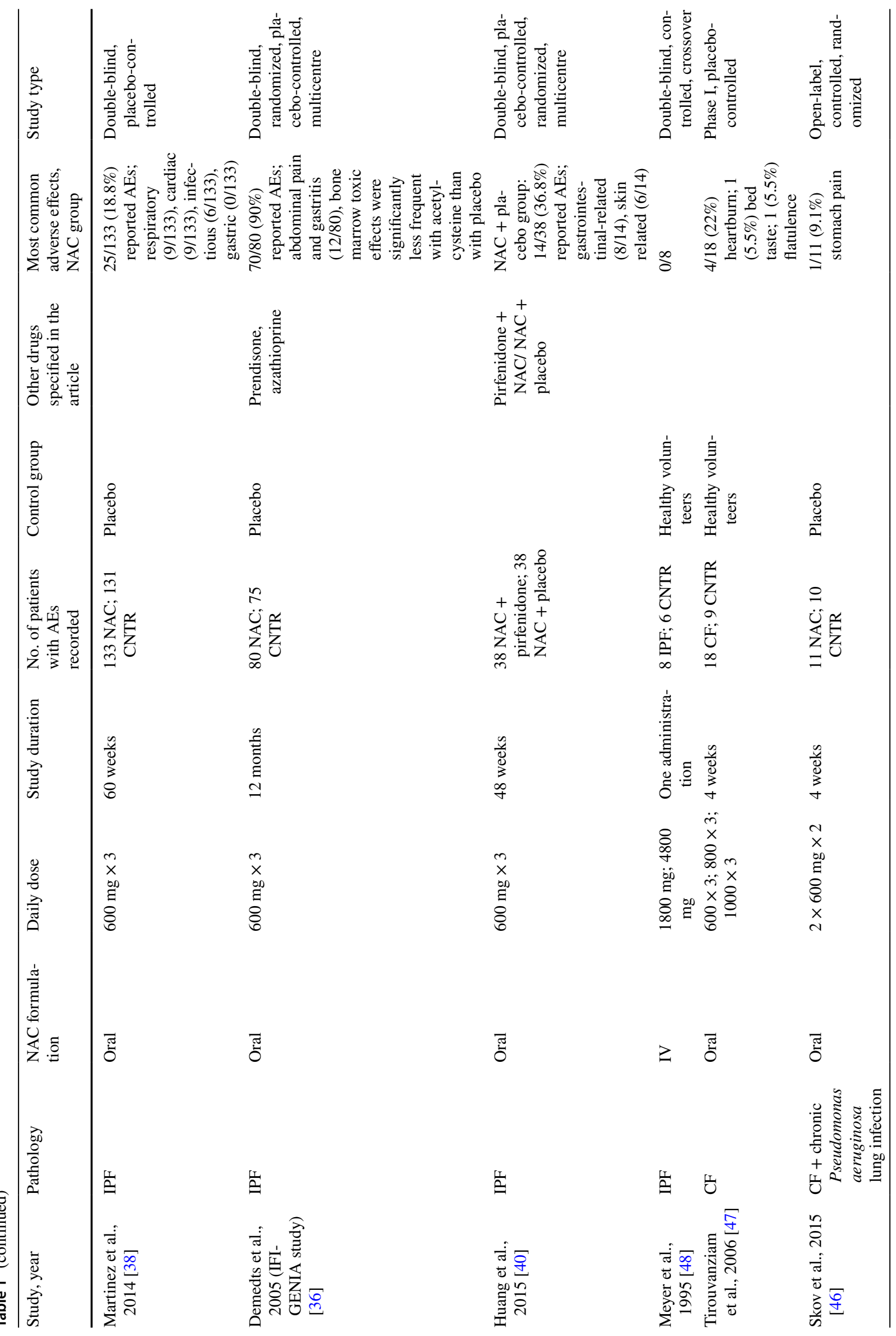


A double-blind, double-dummy comparison between active drug and placebo in two parallel groups explored the effect of NAC $600 \mathrm{mg} /$ day on the concentration of $\mathrm{H}_{2} \mathrm{O}_{2}$ and thiobarbituric acid reactive substances (TBARs) in expired breath condensate and serum levels of two lipid peroxidation products (TBARs, lipid peroxides). Forty-four patients with stable COPD were enrolled and completed the study [16] 22 were assigned to NAC and 22 to placebo. The study was an extension of the protocol for the BREATHE project involving 44 patients (of the 295 in the BREATHE project [17]). In the 12-month period of the study, two patients in the NAC group and three in the placebo group experienced gastrointestinal discomfort, pyrosis, and epigastralgia. The authors affirmed that there was a low rate of adverse events and noted that there were no clinically significant changes in haematology, serum chemistry, electrocardiography or urine analysis in both groups.

In the BRONCUS study [18], the effect of NAC on disease progression and exacerbation rate in patients with moderate to severe COPD was evaluated using a multicentre, randomized, double-blind, placebo-controlled design. The study enrolled 523 patients; 256 were treated with NAC 600 $\mathrm{mg} /$ day and 267 were allocated to placebo. After 3 years of treatment, 186 patients allocated to NAC completed the study (vs. 168 in the placebo group). Among the 2809 adverse events reported (1428 in the NAC group and 1381 in the placebo group), most were related to COPD exacerbations (e.g. bronchitis, rhinitis, cough and dyspnoea), and no adverse events were thought to be drug-related. In the study, no significant differences in adverse event rates were found between the treated and placebo groups, even when considering the specific digestive/gastrointestinal symptoms (Table 2). The study did not achieve its primary endpoint of changing the rate of decline of forced expiratory volume in the first second of expiration $\left(\mathrm{FEV}_{1}\right)$ but did decrease the number of COPD exacerbations in patients not taking inhaled corticosteroids. Given the safety of NAC, the authors suggested that the efficacy of NAC on COPD exacerbation should be tested at higher doses.

In their meta-analysis, Cazzola et al. [19] examined data from 13 studies on NAC treatment in COPD, exploring the effect of high ( $>600 \mathrm{mg} / \mathrm{day}$ up to $1200 \mathrm{mg} / \mathrm{day}$ ) versus low doses $(\leq 600 \mathrm{mg} /$ day $)$. The authors concluded that high doses should be administered to prevent exacerbations in COPD. Overall, these authors did not find evidence that NAC significantly increased the risk of adverse effects (mainly gastrointestinal disorders) compared with placebo, nor was there any evidence that the risk of an adverse reaction was dose-dependent.

Thus, the safety data on oral NAC $600 \mathrm{mg}$ daily in respiratory disease showed that the treatment is well tolerated and the adverse events reported (mostly gastrointestinal) were not more frequent than with placebo. 


\subsection{NAC $1200 \mathrm{mg} / \mathrm{day}$}

\subsubsection{Chronic Bronchitis}

Hansen et al. [20] evaluated general well-being in a multicentre, randomized, parallel group, placebo-controlled study on the efficacy of NAC on chronic bronchitis. Seventyfive patients were assigned to NAC $1200 \mathrm{mg}$ (two 300-mg controlled-release tablets twice daily) and 78 patients were assigned to placebo. After 22 weeks of treatment, no serious adverse events were recorded; however, one patient experienced dizziness, leg pain, headache and palpitations, leading to withdrawal from the study.

\subsubsection{COPD}

A large study of Chinese patients with COPD evaluated the effects of oral NAC $600 \mathrm{mg}$ twice daily on preventing acute exacerbation, in a multicentre, prospective, randomized, double-blind, placebo-controlled, parallel-group trial. The PANTHEON study [21] enrolled a total of 1006 patients who were randomly assigned to NAC $1200 \mathrm{mg}$ daily ( $n=504$; one 600-mg tablet twice daily) or placebo $(n=502)$ in addition to their usual therapy. The study lasted for 12 months and NAC treatment or placebo was added to existing individual therapy. The study concluded that longterm use of NAC $1200 \mathrm{mg}$ daily is useful in preventing exacerbations, especially when disease is of moderate severity. Safety analysis was performed on all patients who received at least one dose of the study drug. Among the 146 patients who had adverse effects in the treated group, 44 (9\%) had adverse events possibly related to the study product, as did 34 (of 130 [26\%]) patients who received placebo $(p=0.29$ ). The most frequently reported adverse events were upper and lower respiratory tract infections, gastrointestinal pain, epigastric discomfort, pruritus, dizziness and diarrhoea. Forty-eight (10\%) patients who received NAC and 46 (9\%) patients who received placebo had serious adverse events, such as hospitalization due to COPD, coronary artery disease, cerebral infarction, upper and lower respiratory tract infection, and osteoarthropathy. Five patients (four from the NAC group) died during the study but clinicians did not consider any of the deaths to be related to treatment. The authors observed that the overall safety profile of NAC 1200 $\mathrm{mg} /$ day was consistent with the established safety profile of NAC $600 \mathrm{mg} /$ day.

A similar safety profile was found in a smaller, doubleblinded, randomized, placebo-controlled trial (HIACE) [22] that evaluated the effect of high doses of NAC (1200 $\mathrm{mg}$; $600 \mathrm{mg}$ effervescent tablets twice daily) on air trapping and airway resistance of COPD. All patients continued their standard therapy. An improvement in small airway function and a decrease in the frequency of exacerbations was recorded in the group taking the higher NAC dose. Among the 58 patients assigned to NAC for 1 year, 5.2\% showed mild adverse effects, mainly gastrointestinal symptoms (diarrhoea, gastroesophageal reflux disease). This rate was similar in the placebo group $(n=62)$, i.e. five patients (8\%) experienced adverse effects. Three patients died for reasons considered to be unrelated to treatment. A post hoc analysis [23] of the HIACE data did not reveal differences in terms of safety between the high and low exacerbation risk subgroups.

In a smaller, randomized, double-blind, crossover study, 24 patients with moderate to severe COPD were allocated to NAC $1200 \mathrm{mg}$ (600 mg twice daily) or placebo for 6 weeks and switched to the other condition for another 6 weeks (after a 2-week washout period). The authors recorded only mild epigastric discomfort in a few patients in the treatment group [24].

In the randomized, double-blind, placebo-controlled trial by Black et al. [25], 50 patients admitted to the hospital for acute COPD exacerbations were enrolled and were randomly assigned to placebo $(n=25)$ or oral NAC $600 \mathrm{mg}$ effervescent tablets two times daily $(n=25)$ in addition to the standard treatment prescribed for their exacerbation. NAC or placebo treatment was continued for 7 days or until discharge. One of the patients treated with NAC reported nausea, compared with two of the patients treated with placebo, and there were no serious adverse events.

Zhang et al. [26] tested the efficacy of NAC on patients with COPD with different genotypes. Three hundred and sixty-eight patients were classified into two groups with different polymorphisms in their HO-1 gene promoter with or without the $\mathrm{L}$ allele. All patients were allocated to standard therapy plus NAC $600 \mathrm{mg}$ twice daily over a 1-year period. In both groups, patients reported gastrointestinal complaints (8 in the L+ group and 15 in the L- group) and no other major adverse events occurred. Ten patients died during the study but no deaths were considered to be related to the study products.

In 2015, while reviewing the available data on oral NAC, Cazzola et al. [19] noted that patients with COPD taking NAC $1200 \mathrm{mg} /$ day had no more adverse effects than those receiving placebo.

A recent meta-analysis aiming to compare the efficacy of erdosteine, carbocysteine, and high-dose NAC (1200 mg/ day) on the risk of acute exacerbation of COPD compared with placebo explored safety as a secondary endpoint [27]. In terms of safety, the authors concluded that among 523 patients chronically treated with NAC $1200 \mathrm{mg} /$ day, about $18 \%$ had mild and well-tolerated adverse effects, with respiratory tract infection being the most common (10.85\%) followed by gastrointestinal disorders (4\%).

Many studies on NAC have been performed on non-White populations, raising the question of the possible different 
Table 2 BRONCHUS and PANTHEON studies: treatment-emergent adverse events considered as being related to treatment, sorted by system organ class and preferred term

\begin{tabular}{|c|c|c|c|c|c|c|c|c|c|}
\hline \multicolumn{5}{|c|}{ BRONCUS: NAC $600 \mathrm{mg} /$ day; safety population ${ }^{\mathrm{a}}$} & \multicolumn{5}{|c|}{$\begin{array}{l}\text { PANTHEON: NAC } 600 \mathrm{mg} \text { twice daily }(1200 \mathrm{mg} / \text { day }) \text {; safety } \\
\text { population }^{\text {b }}\end{array}$} \\
\hline \multirow{2}{*}{$\begin{array}{l}\text { Body } \\
\text { system/pre- } \\
\text { ferred term }\end{array}$} & \multicolumn{2}{|c|}{ NAC $600 \mathrm{mg}[n=256]$} & \multicolumn{2}{|c|}{ Placebo $[n=267]$} & \multirow{2}{*}{$\begin{array}{l}\text { Body } \\
\text { system/pre- } \\
\text { ferred term }\end{array}$} & \multicolumn{2}{|c|}{$\begin{array}{l}\text { NAC } 600 \mathrm{mg} \text { twice daily } \\
{[n=495]}\end{array}$} & \multicolumn{2}{|c|}{ Placebo $[n=495]$} \\
\hline & $\begin{array}{l}\text { No. of } \\
\text { events }\end{array}$ & $\begin{array}{l}\text { No. }(\%) \text { of } \\
\text { patients }\end{array}$ & $\begin{array}{l}\text { No. of } \\
\text { events }\end{array}$ & $\begin{array}{l}\text { No. }(\%) \text { of } \\
\text { patients }\end{array}$ & & $\begin{array}{l}\text { No. of } \\
\text { events }\end{array}$ & $\begin{array}{l}\text { No. }(\%) \text { of } \\
\text { patients }\end{array}$ & $\begin{array}{l}\text { No. of } \\
\text { events }\end{array}$ & $\begin{array}{l}\text { No. }(\%) \text { of } \\
\text { patients }\end{array}$ \\
\hline $\begin{array}{l}\text { Patients with } \\
\text { at least one } \\
\text { definitely/ } \\
\text { possibly/ } \\
\text { probably } \\
\text { related } \\
\text { adverse } \\
\text { event }\end{array}$ & 31 & $23(9.0)$ & 38 & $23(8.6)$ & $\begin{array}{l}\text { Patients with } \\
\text { at least one } \\
\text { definitely/ } \\
\text { possibly/ } \\
\text { probably } \\
\text { related } \\
\text { adverse } \\
\text { event }\end{array}$ & 51 & $44(8.89)$ & 73 & $34(6.87)$ \\
\hline $\begin{array}{l}\text { Body as a } \\
\text { whole }\end{array}$ & & & & & $\begin{array}{l}\text { Body as a } \\
\text { whole }\end{array}$ & & & & \\
\hline \multirow{2}{*}{$\begin{array}{l}\text { Allergic } \\
\text { reaction }\end{array}$} & 1 & $1(0.4)$ & 0 & $0(0.0)$ & & & & & \\
\hline & & & & & Fatigue & 0 & $0(0.00)$ & 1 & $1(0.20)$ \\
\hline Hernia & 1 & $1(0.4)$ & 0 & $0(0.0)$ & & & & & \\
\hline \multirow[t]{2}{*}{ Neoplasm } & 0 & $0(0.0)$ & 1 & $1(0.4)$ & & & & & \\
\hline & & & & & $\begin{array}{c}\text { Mucosal } \\
\text { dryness }\end{array}$ & 1 & $1(0.20)$ & 0 & $0(0.00)$ \\
\hline $\begin{array}{l}\text { Cardiovas- } \\
\text { cular }\end{array}$ & & & & & $\begin{array}{l}\text { Cardiovas- } \\
\text { cular }\end{array}$ & & & & \\
\hline $\begin{array}{l}\text { Hyperten- } \\
\text { sion }\end{array}$ & 0 & $0(0.0)$ & 1 & $1(0.4)$ & & & & & \\
\hline \multirow[t]{4}{*}{ Palpitation } & 1 & $1(0.4)$ & 0 & $0(0.0)$ & & & & & \\
\hline & & & & & $\begin{array}{l}\text { Angina } \\
\text { unstable }\end{array}$ & 0 & $0(0.00)$ & 1 & $1(0.20)$ \\
\hline & & & & & $\begin{array}{c}\text { Coronary } \\
\text { artery } \\
\text { disease }\end{array}$ & 1 & $1(0.20)$ & 0 & $0(0.00)$ \\
\hline & & & & & $\begin{array}{l}\text { Extrasysto- } \\
\text { les }\end{array}$ & 0 & $0(0.00)$ & 2 & $1(0.20)$ \\
\hline Digestive & & & & & Digestive & & & & \\
\hline \multirow[t]{2}{*}{$\begin{array}{l}\text { Abdominal } \\
\text { pain }\end{array}$} & 6 & $4(1.6)$ & 2 & $2(0.7)$ & $\begin{array}{l}\text { Abdominal } \\
\text { pain }\end{array}$ & 4 & $4(0.81)$ & 0 & $0(0.00)$ \\
\hline & & & & & $\begin{array}{l}\text { Gastrointes- } \\
\text { tinal pain }\end{array}$ & 9 & $8(1.62)$ & 10 & 7 (1.41) \\
\hline Dyspepsia & 6 & $3(1.2)$ & 18 & $7(2.6)$ & Dyspepsia & 1 & $1(0.20)$ & 3 & $3(0.61)$ \\
\hline Nausea & 4 & $4(1.6)$ & 1 & $1(0.4)$ & Nausea & 6 & $4(0.81)$ & 3 & $1(0.20)$ \\
\hline Diarrhoea & 0 & $0(0.0)$ & 2 & $1(0.4)$ & Diarrhoea & 2 & $2(0.40)$ & 3 & $3(0.61)$ \\
\hline $\begin{array}{l}\text { Dilation of } \\
\text { stomach }\end{array}$ & 1 & $1(0.4)$ & 0 & $0(0.0)$ & $\begin{array}{l}\text { Abdominal } \\
\text { discomfort }\end{array}$ & 1 & $1(0.20)$ & 0 & $0(0.00)$ \\
\hline Flatulence & 1 & $1(0.4)$ & 1 & $1(0.4)$ & $\begin{array}{r}\text { Abdominal } \\
\text { distension }\end{array}$ & 2 & $2(0.40)$ & 0 & $0(0.00)$ \\
\hline Gastritis & 1 & $1(0.4)$ & 1 & $1(0.4)$ & $\begin{array}{l}\text { Epigastric } \\
\text { discomfort }\end{array}$ & 5 & $5(1.01)$ & 8 & $6(1.21)$ \\
\hline Vomiting & 1 & $1(0.4)$ & 0 & $0(0.0)$ & Eructation & 1 & $1(0.20)$ & 0 & $0(0.00)$ \\
\hline Constipation & 0 & $0(0.0)$ & 1 & $1(0.4)$ & $\begin{array}{l}\text { Gastric } \\
\text { infection }\end{array}$ & 1 & $1(0.20)$ & 0 & $0(0.00)$ \\
\hline $\begin{array}{l}\text { Duodenal } \\
\text { ulcer }\end{array}$ & 0 & $0(0.0)$ & 1 & $1(0.4)$ & Gastric ulcer & 1 & $1(0.20)$ & 0 & $0(0.00)$ \\
\hline
\end{tabular}


Table 2 (continued)

BRONCUS: NAC $600 \mathrm{mg} /$ day; safety population ${ }^{\mathrm{a}}$

\begin{tabular}{|c|c|c|c|c|c|c|c|c|c|}
\hline \multirow{2}{*}{$\begin{array}{l}\text { Body } \\
\text { system/pre- } \\
\text { ferred term }\end{array}$} & \multicolumn{2}{|c|}{ NAC $600 \mathrm{mg}[n=256]$} & \multicolumn{2}{|c|}{ Placebo $[n=267]$} & \multirow{2}{*}{$\begin{array}{l}\text { Body } \\
\text { system/pre- } \\
\text { ferred term }\end{array}$} & \multicolumn{2}{|c|}{$\begin{array}{l}\text { NAC } 600 \mathrm{mg} \text { twice daily } \\
{[n=495]}\end{array}$} & \multicolumn{2}{|c|}{ Placebo $[n=495]$} \\
\hline & $\begin{array}{l}\text { No. of } \\
\text { events }\end{array}$ & $\begin{array}{l}\text { No. (\%) of } \\
\text { patients }\end{array}$ & $\begin{array}{l}\text { No. of } \\
\text { events }\end{array}$ & $\begin{array}{l}\text { No. }(\%) \text { of } \\
\text { patients }\end{array}$ & & $\begin{array}{l}\text { No. of } \\
\text { events }\end{array}$ & $\begin{array}{l}\text { No. }(\%) \text { of } \\
\text { patients }\end{array}$ & $\begin{array}{l}\text { No. of } \\
\text { events }\end{array}$ & $\begin{array}{l}\text { No. }(\%) \text { of } \\
\text { patients }\end{array}$ \\
\hline $\begin{array}{c}\text { Gastroin- } \\
\text { testinal } \\
\text { disorder }\end{array}$ & 0 & $0(0.0)$ & 1 & $1(0.4)$ & $\begin{array}{c}\text { Gastroin- } \\
\text { testinal } \\
\text { disorder }\end{array}$ & 1 & $1(0.20)$ & 0 & $0(0.00)$ \\
\hline Sialadenitis & 0 & $0(0.0)$ & 1 & $1(0.4)$ & $\begin{array}{l}\text { Gastroe- } \\
\text { sophageal } \\
\text { reflux }\end{array}$ & 1 & $1(0.20)$ & 4 & $3(0.20)$ \\
\hline $\begin{array}{l}\text { Stomach } \\
\text { ulcer }\end{array}$ & 0 & $0(0.0)$ & 1 & $1(0.4)$ & $\begin{array}{c}\text { Colonic } \\
\text { polyp }\end{array}$ & 0 & $0(0.00)$ & 1 & $1(0.20)$ \\
\hline \multirow{4}{*}{$\begin{array}{l}\text { Chest pain } \\
\text { substernal }\end{array}$} & 1 & $1(0.4)$ & 0 & $0(0.0)$ & Constipation & 0 & $0(0.00)$ & 3 & $1(0.20)$ \\
\hline & & & & & Gingivitis & 0 & $0(0.00)$ & 2 & $1(0.20)$ \\
\hline & & & & & $\begin{array}{l}\text { Mouth } \\
\text { ulceration }\end{array}$ & 0 & $0(0.00)$ & 1 & $1(0.20)$ \\
\hline & & & & & Toothache & 0 & $0(0.00)$ & 2 & $2(0.40)$ \\
\hline $\begin{array}{l}\text { Metabolic } \\
\text { and nutri- } \\
\text { tional }\end{array}$ & & & & & $\begin{array}{l}\text { Metabolic } \\
\text { and nutri- } \\
\text { tional }\end{array}$ & & & & \\
\hline \multirow[t]{2}{*}{ Gout } & 0 & $0(0.0)$ & 1 & $1(0.4)$ & & & & & \\
\hline & & & & & $\begin{array}{l}\text { Decreased } \\
\text { appetite }\end{array}$ & 0 & $0(0.00)$ & 1 & $1(0.20)$ \\
\hline \multirow[t]{4}{*}{$\begin{array}{l}\text { Musculo- } \\
\text { skeletal }\end{array}$} & & & & & $\begin{array}{r}\text { Musculo- } \\
\text { skeletal }\end{array}$ & & & & \\
\hline & & & & & $\begin{array}{l}\text { Bone metab- } \\
\text { olism } \\
\text { disorder }\end{array}$ & 0 & $0(0.00)$ & 1 & $1(0.20)$ \\
\hline & & & & & Bone pain & 0 & $0(0.00)$ & 2 & $2(0.40)$ \\
\hline & & & & & $\begin{array}{l}\text { Muscle } \\
\text { oedema }\end{array}$ & 0 & $0(0.00)$ & 5 & $1(0.20)$ \\
\hline Nervous & & & & & Nervous & & & & \\
\hline \multirow[t]{4}{*}{ Tremor } & 1 & $1(0.4)$ & 0 & $0(0.0)$ & Tremor & 1 & $1(0.20)$ & 0 & $0(0.00)$ \\
\hline & & & & & Headache & 0 & $0(0.00)$ & 1 & $1(0.20)$ \\
\hline & & & & & Dizziness & 0 & $0(0.00)$ & 4 & $4(0.81)$ \\
\hline & & & & & $\begin{array}{l}\text { Poor quality } \\
\text { sleep }\end{array}$ & 0 & $0(0.00)$ & 1 & $1(0.20)$ \\
\hline Respiratory & & & & & Respiratory & & & & \\
\hline \multirow[t]{2}{*}{ Bronchitis } & 1 & $1(0.4)$ & 3 & $3(1.1)$ & & & & & \\
\hline & & & & & $\begin{array}{l}\text { Rhinitis } \\
\text { allergic }\end{array}$ & 1 & $1(0.20)$ & 0 & $0(0.00)$ \\
\hline \multirow{2}{*}{$\begin{array}{l}\text { Cough } \\
\text { increased }\end{array}$} & 1 & $1(0.4)$ & 0 & $0(0.0)$ & Cough & 2 & $2(0.40)$ & 0 & $0(0.00)$ \\
\hline & & & & & Dyspnoea & 1 & $1(0.20)$ & 0 & $0(0.00)$ \\
\hline \multirow[t]{4}{*}{ Pharyngitis } & 1 & $1(0.4)$ & 0 & $0(0.0)$ & & & & & \\
\hline & & & & & $\begin{array}{l}\text { Upper } \\
\text { respiratory } \\
\text { tract infec- } \\
\text { tion }\end{array}$ & 4 & $4(0.81)$ & 4 & $3(0.61)$ \\
\hline & & & & & Chest pain & 0 & $0(0.00)$ & 1 & $1(0.20)$ \\
\hline & & & & & $\begin{array}{l}\text { Chest dis- } \\
\text { comfort }\end{array}$ & 0 & $0(0.00)$ & 1 & $1(0.20)$ \\
\hline
\end{tabular}

PANTHEON: NAC $600 \mathrm{mg}$ twice daily (1200 mg/day); safety population $^{\mathrm{b}}$

metab- 
Table 2 (continued)

BRONCUS: NAC $600 \mathrm{mg} /$ day; safety population ${ }^{\mathrm{a}}$

\begin{tabular}{|c|c|c|c|c|c|c|c|c|c|}
\hline \multirow{2}{*}{$\begin{array}{l}\text { Body } \\
\text { system/pre- } \\
\text { ferred term }\end{array}$} & \multicolumn{2}{|c|}{ NAC $600 \mathrm{mg}[n=256]$} & \multicolumn{2}{|c|}{ Placebo $[n=267]$} & \multirow{2}{*}{$\begin{array}{l}\text { Body } \\
\text { system/pre- } \\
\text { ferred term }\end{array}$} & \multicolumn{2}{|c|}{$\begin{array}{l}\text { NAC } 600 \mathrm{mg} \text { twice daily } \\
{[n=495]}\end{array}$} & \multicolumn{2}{|c|}{ Placebo $[n=495]$} \\
\hline & $\begin{array}{l}\text { No. of } \\
\text { events }\end{array}$ & $\begin{array}{l}\text { No. }(\%) \text { of } \\
\text { patients }\end{array}$ & $\begin{array}{l}\text { No. of } \\
\text { events }\end{array}$ & $\begin{array}{l}\text { No. }(\%) \text { of } \\
\text { patients }\end{array}$ & & $\begin{array}{l}\text { No. of } \\
\text { events }\end{array}$ & $\begin{array}{l}\text { No. }(\%) \text { of } \\
\text { patients }\end{array}$ & $\begin{array}{l}\text { No. of } \\
\text { events }\end{array}$ & $\begin{array}{l}\text { No. }(\%) \text { of } \\
\text { patients }\end{array}$ \\
\hline & & & & & $\begin{array}{l}\text { Musculo- } \\
\text { skeletal } \\
\text { chest pain }\end{array}$ & 0 & $0(0.00)$ & 1 & $1(0.20)$ \\
\hline $\begin{array}{l}\text { Skin and } \\
\quad \text { skin struc- } \\
\text { tures }\end{array}$ & & & & & $\begin{array}{l}\text { Skin and } \\
\text { skin struc- } \\
\text { tures }\end{array}$ & & & & \\
\hline Rash & 0 & $0(0.0)$ & 1 & $1(0.4)$ & Rash pruritic & 0 & $0(0.00)$ & 2 & $2(0.40)$ \\
\hline Pruritus & 1 & $1(0.4)$ & 1 & $1(0.4)$ & Pruritus & 2 & $2(0.40)$ & 0 & $0(0.00)$ \\
\hline Urticaria & 1 & $1(0.4)$ & 0 & $0(0.0)$ & & & & & \\
\hline Urogenital & & & & & Urogenital & & & & \\
\hline \multirow[t]{9}{*}{ Cystitis } & 1 & $1(0.4)$ & 0 & $0(0.0)$ & & & & & \\
\hline & & & & & $\begin{array}{l}\text { Blood and } \\
\text { lymphatic } \\
\text { system } \\
\text { disorders }\end{array}$ & & & & \\
\hline & & & & & $\begin{array}{l}\text { Lymph node } \\
\text { pain }\end{array}$ & 0 & $0(0.00)$ & 2 & $1(0.20)$ \\
\hline & & & & & $\begin{array}{l}\text { Hepato- } \\
\text { biliary } \\
\text { disorders }\end{array}$ & & & & \\
\hline & & & & & $\begin{array}{l}\text { Hepatic } \\
\text { lesion }\end{array}$ & 0 & $0(0.00)$ & 1 & $1(0.20)$ \\
\hline & & & & & $\begin{array}{l}\text { Investiga- } \\
\quad \text { tions }\end{array}$ & & & & \\
\hline & & & & & $\begin{array}{l}\text { Alanine ami- } \\
\text { notrans- } \\
\text { ferase } \\
\text { increased }\end{array}$ & 1 & $1(0.20)$ & 0 & $0(0.00)$ \\
\hline & & & & & $\begin{array}{l}\text { Heart rate } \\
\text { increased }\end{array}$ & 1 & $1(0.20)$ & 0 & $0(0.00)$ \\
\hline & & & & & $\begin{array}{l}\text { Heart rate } \\
\text { irregular }\end{array}$ & 1 & $1(0.20)$ & 2 & $2(0.40)$ \\
\hline
\end{tabular}

$N A C N$-acetylcysteine

a Zambon internal data from the BRONCUS study final report

${ }^{b}$ Zambon internal data from the PANTHEON study final report

effects of NAC in different populations. However, this may be driven by comparing the data on adverse events related to treatment reported in the safety population of the BRONCUS (White) and PANTHEON (Chinese) studies (Table 2). Notably, the number of patients with adverse events considered to be related to study medication was generally low in both studies, and no significant differences in the incidence of adverse events were found between the groups (NAC vs. placebo) in both studies. The type of adverse events reported was similar between the studies and, in particular, the adverse events affecting the digestive system were low

PANTHEON: NAC $600 \mathrm{mg}$ twice daily (1200 mg/day); safety population $^{\mathrm{b}}$ . 
was to assess whether the long-term use of oral NAC (600 $\mathrm{mg}$ twice daily, 12 months) reduced the incidence of exacerbations and improved the quality of life in patients with idiopathic or post-infective bronchiectasis. Eighty-one patients received oral NAC and 80 were in the control group. NAC was added to usual medications (inhaled corticosteroids and long-acting $\beta$-agonist 45 ; inhaled short-acting $\beta$-agonist; inhaled anticholinergics), which did not differ between the two groups. Results show a reduction in the incidence of exacerbations and improvement in quality of life in patients treated with NAC compared with the control group. The time to the first exacerbation was similar between the two groups; however, significantly more patients remained exacerbation-free in the NAC group than in the control group. Serious adverse events were not observed during the study period. The most common adverse events reported were epigastric discomfort $(9.9 \%$ in the NAC group, $7.5 \%$ in controls); abdominal pain (2.5\% in both groups); vomiting $(1.3 \%$ in the NAC group, $5 \%$ in controls); body odour (6.2\% in the NAC group, $0 \%$ in controls); anorexia or nausea (8.6\% in the NAC group, $10 \%$ in controls); diarrhoea (1.2\% in the NAC group, $3.8 \%$ in controls); dyspnoea (2.5\% in the NAC group, $6.3 \%$ in controls); rash (2.5\% in the NAC group, $1.3 \%$ in controls) and hepatic dysfunction consisting of mild elevation of liver enzymes (3.7\% in the NAC group, $2.5 \%$ in controls) and relieved by application of hepatoprotective or antiallergic agents.

\subsection{High Doses}

\subsubsection{COPD}

A study by Hirai et al. [29] evaluated the effects of NAC $1800 \mathrm{mg}$ daily on exercise tolerance in a small group of patients with mild COPD. Nine patients were treated for 4 days. NAC increased circulating glutathione levels compared with placebo, but there were no differences in exercise tolerance; one patient had a mild adverse reaction (bloating and increased intestinal gas) that did not interfere with activities of daily living.

In a longer, randomized, controlled, double-blinded trial by Johnson et al. [30], patients with COPD received oral NAC (effervescent tablets containing NAC $900 \mathrm{mg}$ twice daily) or placebo, in addition to their standard therapy, for 8 weeks. The study was designed to randomize 130 patients, but patient enrolment was stopped in relation to an animal model safety report [31] (see below) when 22 patients had been assigned to placebo and 23 to NAC. The small number of patients precluded any efficacy assessment; NAC was well tolerated and most adverse events were unrelated to the study drug. Mild gastrointestinal symptoms were reported in the NAC group more frequently than in the placebo group $(5 / 23$ vs. $1 / 22)$
Table 3 Adverse events in the PANTHER-IPF study [37]

\begin{tabular}{llll}
\hline & $\begin{array}{l}\text { Combina- } \\
\text { tion therapy } \\
{[n=77]}\end{array}$ & Placebo $[n=78]$ & $p$ value \\
\hline Serious adverse event & & & \\
Any & $24(31)$ & $8(10)$ & 0.001 \\
Respiratory system & $12(16)$ & $4(5)$ & 0.03 \\
Infectious & $5(6)$ & $1(1)$ & 0.12 \\
Gastrointestinal system & $1(1)$ & $3(4)$ & 0.62 \\
Cardiac & $3(4)$ & 0 & 0.12 \\
General disorder & $3(4)$ & 0 & 0.12 \\
Neoplasm & $2(3)$ & 0 & 0.25 \\
Metabolism & $1(1)$ & 0 & 0.50 \\
Musculoskeletal system & 0 & $1(1)$ & 1.00 \\
Nervous system & $1(1)$ & 0 & 0.50 \\
Reproductive system & $1(1)$ & 0 & 0.50 \\
Adverse event & & & \\
Any & $68(88)$ & $61(78)$ & 0.09 \\
General disorder & $34(44)$ & $21(27)$ & 0.03 \\
Skin & $13(17)$ & $4(5)$ & 0.02 \\
Renal and urinary & $10(13)$ & $1(1)$ & 0.005 \\
system & & & \\
\hline
\end{tabular}

Data are expressed as number of patients (\%)

${ }^{a}$ Included in this category were all serious adverse events that did not fall into another body-system category, including adverse drug reactions and drug fever

${ }^{\mathrm{b}}$ Listed are specific adverse events with a significant between-group difference

The mice model studied by Sayin et al. [31] suggested that antioxidant supplementation (NAC or vitamin E) speeds up progression of non-small-cell lung cancer in tumourprone mouse models with no role in tumour initiation and/ or chemoprevention. Furthermore, it is not obvious how an effect found in established lung cancer caused by mutation in K-ras or B-raf in a mouse model relates to clinical practice. Considering that NAC has a long history and has been widely used and studied, it seems reasonable to believe that if NAC had a cancer-promoting effect in man, it would be evident by now. At present, the clinical benefits gained by patients with chronic respiratory conditions outweigh the unsubstantiated risk of promoting lung cancer. Other studies [32-34] used $1800 \mathrm{mg} /$ day doses in patients with COPD, but information on safety was not clearly reported.

\subsubsection{Idiopathic Pulmonary Fibrosis}

Many trials have used oral NAC $1800 \mathrm{mg} /$ day in IPF. A dose of $1800 \mathrm{mg} /$ day was tested in 18 patients with an established diagnosis of IPF [35]. Patients were treated with 600 mg NAC three times daily for 12 weeks in addition to their 
latest immunosuppressive therapy. The sample was small and seven patients experienced temporary gastrointestinal symptoms (diarrhoea, mild nausea); coughing was intensified in three patients (17\%) and improved in one patient $(6 \%)$. Increased amounts of sputum were reported by three patients (17\%).

The IFIGENIA trial was the first controlled study to assess the efficacy of NAC (effervescent tablets $600 \mathrm{mg}$ three times daily) added to standard therapy (prednisone and azathioprine) in IPF [36]. In this double-blind, randomized, placebo-controlled multicentre study, 182 patients were randomly assigned to treatment (92 to NAC and 90 to placebo), and 80 and 51 patients, respectively, completed the 1-year period of treatment. In the treated group, NAC added to therapy preserved vital capacity and diffusing capacity of lung for carbon monoxide (DLCO) in patients with IPF better than standard therapy alone. The overall incidence of adverse effects did not differ between the groups, with the exception of those related to bone marrow toxicity, which was more frequent in controls (4\% vs. 13\%). Although the authors concluded that adding NAC at high doses to prednisone and azathioprine in IPF treatment was well tolerated, the lack of placebo groups for prednisone and azathioprine meant that there was no consensus about the safety and efficacy of NAC in this condition.

Other trials were designed to further explore this topic. The PANTHER-IPF trial explored efficacy in terms of preservation of forced vital capacity of the three-drug regimen versus NAC alone [37]. In this randomized, double-blind, placebo-controlled trial, patients with IPF with mild to moderate impairment in lung function were assigned to one of the following groups: combination therapy (prednisone, azathioprine, and NAC), NAC alone, or placebo. NAC was prescribed at $600 \mathrm{mg}$ orally three times daily. In an interim analysis performed at about $50 \%$ of enrolment, increased rates of death and hospitalization were found in the group receiving the combination therapy regimen (77 patients) compared with placebo, and that arm of the study was stopped (at about 32 weeks of the 60 weeks planned), but the trial continued as a two-group study (133 patients taking NAC 1800 $\mathrm{mg}$ daily vs. 131 receiving placebo). After 60 weeks, the rate of deaths was similar in both groups; frequencies of serious adverse events (respiratory, infectious, cardiac and gastrointestinal) did not significantly differ between the groups except for cardiac disorders, which were more frequent in the NAC group (6.8\% vs. $1.4 \%)$, and gastrointestinal complaints, reported in the placebo (4.6\%) group but not in the NAC group [38] (Table 3). The underlying mechanisms and the characterization of these events remain unclear. It should be noted that cardiac comorbidities are quite common in IPF patients [39] and the placebo arm of the study was not exempted from these events. The analysis of the postmarketing database of all available safety data collected in almost
50 years (marketing authorization for oral NAC was received in 1972) and obtained from more than 800 million exposed patients, did not raise safety concerns, including effects on cardiovascular and hepatic systems (Zambon internal data).

Some studies were designed to further explore the rationale of adding NAC at high doses to other types of IPF treatment. Huang et al. [40] performed a double-blind, placebo-controlled, randomized, multicentre clinical trial on 76 Chinese patients with IPF with mild to moderate impairment of pulmonary function randomly allocated to pirfenidone $(n=38)$ or placebo $(n=38)$ plus NAC $1800 \mathrm{mg}$ (600 mg three times daily) for 48 weeks. Patients were assessed at weeks 1, 2, 4, 12, 24, 36 and 48. Primary endpoints were the change in forced vital capacity in the maximal distance on the 6-minute walk test from baseline to week 48 . Safety was evaluated at each visit based on clinical and laboratory findings as well as adverse events. In the pirfenidone + NAC group, the rate of adverse events was significantly higher than in the placebo + NAC group ( $52.63 \%$ vs. $26.3 \%, p=0.03$ ). Mild to moderate skinrelated adverse events were reported more frequently in the pirferidone + NAC group, and were reported as reversible and without any clinical sequela. Liver impairment was also reported; in two patients (2.7\%) aspartate aminotransferase (AST) levels were more than threefold above the upper limit of normal. Three patients dropped out of this group because of adverse events (rash, back pain, increase in alanine aminotransferase (ALT) and AST levels). Gastrointestinal and skin related events were the most commonly reported adverse events; these were almost always mild to moderate in severity and rarely led to treatment discontinuation. Elevations ( $>3 \times$ upper limit of normal) in ALT or AST occurred in 21/789 (2.7\%) patients; the adjusted incidence of AST/ALT elevations was 1.7 per 100 patient exposure years.

Gastrointestinal-related events, weight loss, back pain, and changes in hepatic function were reported equally in the two groups. Two patients in each group died as a result of serious adverse events related to IPF. The authors concluded that the association of high-dose NAC and pirfenidone is generally well tolerated and prolonged progression-free survival in their population.

Another multicentre, double-blind, randomized trial (PANORAMA study) evaluated the association of NAC and pirfenidone [41]. The primary aim of that study was to assess the safety of a treatment regimen commonly used in clinical practice. Patients were randomly allocated to pirfenidone (at least $1602 \mathrm{mg} / \mathrm{day}$ ) and NAC (600 mg dispersible tablets three times daily) or pirfenidone and placebo. Among the 61 patients in the treated group, 51 completed the 24-week study period (55/62 in the placebo group). Adverse events were collected at baseline, at each study visit and at followup (28 days after the final dose of study drug). Seventy-nine 
percent of the patients reported 322 treatment-emergent mild or moderate adverse events, most of which were considered unrelated to the study treatment. Of the treatment-emergent adverse events reported by more than $5 \%$ of patients overall (cough, photosensitivity reaction, nasopharyngitis, diarrhoea, nausea, dyspnoea, bronchitis, upper respiratory tract infection), photosensitivity was more frequently reported in the NAC group compared with the placebo group (13\% vs. $2 \%)$; cardiac adverse events were reported by one patient receiving NAC (atrial fibrillation) and by two patients receiving placebo (arrhythmia and atrial fibrillation). Only one severe adverse event of diarrhoea reported in the NAC group was considered to be related to treatment and the patient dropped out of the study. A further three patients discontinued NAC and pirfenidone due to nausea (considered related to treatment) and rash (considered related to treatment). Seven patients experienced serious treatmentemergent adverse events, but none were considered related to treatment. Four deaths occurred during the study, but they were not considered to be related to treatment. The authors did not find a clinical advantage in the association of NAC and pirfenidone and concluded that although safety data did not suggest that NAC affected the tolerability of pirfenidone, their findings did not support a rationale for combining the two drugs.

A further analysis of the PANTHER data considering the interaction between genotype (single nucleotide polymorphisms within TOLLIP and MUC5B) and the drug administered highlighted the interaction between NAC and some specific polymorphisms [39]. The results were replicated in an independent cohort of patients, indicating that the effects of NAC on patients with IPF depend on genotype characteristics. The authors observed good efficacy of NAC in patients with IPF with a rs3750920 (TOLLIP) TT genotype, but a trend towards harm in those with a CC genotype was also reported. These findings highlight that it is important to consider the susceptibility of different genotypes to the effects of NAC when exploring its efficacy and safety in patients with IPF.

\subsubsection{Cystic Fibrosis}

NAC has been reported to reduce the viscosity of sputum in both $\mathrm{CF}$ and COPD, facilitating the removal of pulmonary secretions [42]. Moreover, by maintaining airway clearance, it could prevent bacterial stimulation of mucin production and hence mucus hypersecretion [43].

The use of thiol derivates such as NAC in CF is still a matter of debate. A review concluded that evidence to support the prescription of these compounds in clinical practice is still poor, but further studies were encouraged due to some promising results [44].
Subsequently, one study included 70 patients with CF who received NAC $(900 \mathrm{mg})$ or placebo orally three times daily for 24 weeks [45]. Stable or slightly increased lung function was observed in the treated group (mean $\mathrm{FEV}_{1}$ at baseline $62.9 \pm 13.4$ ). Conversely, the control group showed a 4-6\% reduction in lung function compared with baseline (mean $\mathrm{FEV}_{1}$ at baseline $63.8 \pm 13.2$ ).

Similarly, in an open-label, controlled, randomized study, Skov et al. [46] evaluated the effect of 4 weeks of oral NAC treatment (1200 mg three times daily) on the biochemical parameters of oxidative stress in adults with $\mathrm{CF}$ and chronic lung infection due to Pseudomonas aeruginosa, and found an improvement in lung function although this was not significant. Among the 11 patients in the treated group, one discontinued NAC due to stomach pain; no other adverse events were observed. The treatment was considered well tolerated and worthy of further investigations on larger samples to assess its potential clinical efficacy.

$\mathrm{CF}$ is characterized by recurrent and chronic respiratory tract infections with polymorphonuclear neutrophil inflammation. As a consequence, there is an increased burden from oxidative stress, which can be counteracted by increasing glutathione production with NAC. To evaluate the efficacy of NAC in this theoretical frame, Tirouvanziam et al. [47] designed an unblinded dose-escalation tolerability and exploratory efficacy phase I trial where 18 patients with $\mathrm{CF}$ were assigned to NAC treatment $(0.6,0.8$, and 1.0 $\mathrm{g}$ /day three times daily) for a 4-week period. The authors found that short-term high-dose oral NAC treatment significantly increased glutathione levels in blood neutrophils and whole-blood glutathione levels in patients with CF. The treatment proved to be well tolerated at all three doses and mild adverse effects were reported, such as bad taste, heartburn, nausea, flatulence.

\section{Other Formulations}

Oral NAC is the most commonly used formulation in respiratory diseases but some studies explored the safety of other formulations in some of these conditions.

\subsection{Intravenous NAC}

In their study, Meyer et al. [48] administered NAC intravenously to eight patients with IPF and six healthy controls. The two administrations were $500 \mathrm{~mL}$ of glucose solution containing $1800 \mathrm{mg}$ of NAC and $4800 \mathrm{mg}$ of NAC added to glucose solution. Each patient received both doses in random order, with 1 week intervening between administrations. Healthy individuals received three different doses of NAC each week (600 mg, $1800 \mathrm{mg}$ and $4800 \mathrm{mg}$ ). The safety 
evaluation revealed no adverse events associated with the study drug, which did not affect the lower respiratory tract.

\subsection{Inhaled NAC}

\subsubsection{Idiopathic Pulmonary Fibrosis}

It has been hypothesized that treatment with high doses of NAC may repair an oxidant-antioxidant imbalance that occurs in the lung tissue of patients with IPF. The use of NAC in IPF is therefore a topic of increasing interest. In a prospective, controlled, randomized, multicentre, clinical trial performed in Japan, Homma et al. [49] enrolled 100 patients with IPF and randomly assigned them to an NAC group (352.4 mg twice daily by inhalation) or a control group. The study lasted for 48 weeks and data on safety were recorded on 90 patients and efficacy on 76 (38 in the NAC group and 38 in the control group) due to non-administration of NAC, protocol violations or missing data. Common reported adverse events were bacterial pneumonia, cough, sore throat, and hypercholesterolaemia, but there was no difference in terms of the number of adverse events between the groups. Furthermore, the authors commented that treatment with NAC was generally well tolerated because the severity of the adverse events did not reach grade 2 on the grading scale used [Common Terminology Criteria for Adverse Events (CTCAE) v3.0; https://ctep.cancer.gov/].

A study by Okuda et al. [50] enrolled 28 patients with mild to moderate IPF in their single-centre, single-arm, prospective clinical trial. Inhaled NAC (352.4 mg twice daily) was administered for 26 weeks and changes in forced vital capacity were recorded. Data on changes 26 weeks before NAC administration were compared with data on changes in the 26 weeks of NAC treatment. Inhaled NAC significantly attenuated the decline in forced vital capacity in cases of mild to moderate IPF. Two patients experienced adverse events (drug-induced pneumonitis and cough), which partially and completely improved by discontinuing NAC inhalation. One patient experienced mild mediastinal emphysema but was able to continue inhaled NAC therapy. Overall, the authors conclude that inhaled NAC was well tolerated considering that the severity of the adverse events was generally mild to moderate.

In their retrospective observational study on patients with early untreated IPF, Muramatsu et al. [51] explored the effect of 12 months of treatment with inhaled NAC $(352.4 \mathrm{mg}$ twice daily dissolved in saline solution to a volume of 6 $\mathrm{mL}$ ) on 22 patients. They aimed to study the effect of NAC monotherapy on the systemic oxidant-antioxidant imbalance in patients with IPF, and they measured the status of redox balance in whole-blood and urine samples (compared with a control group of healthy volunteers) as well as the clinical effects. More than half of the patients experienced some mild adverse events (12/22 cough, and 3/22 discomfort of the pharynx), which did not prevent them from continuing the treatment. The study concluded good efficacy of NAC inhaled therapy associated with an improved redox balance; however, the lack of a placebo control group decreases the strength of the results and makes it difficult to attribute adverse effects to treatment with certainty.

In a recent case-control study, Sakamoto et al. [52] used inhaled NAC in combination with pirfenidone in 34 patients with IPF treated for 12 months (a control group was treated with pirfenidone alone). Patients in the experimental group received inhaled NAC twice daily (352.4 mg diluted with saline to a total volume of $6 \mathrm{~mL}$ ) in addition to pirfenidone (1800 mg/day). Most of the adverse effects observed in the NAC plus pirfenidone group (assessed using the grading scale of the CTCAE v3.01; https://ctep.cancer.gov/) resolved after reducing or temporarily discontinuing pirfenidone. Inhaled NAC was therefore considered well tolerated in this group because the adverse effects were related to pirfenidone therapy.

Only one older study evaluated higher doses. Borok et al. [53] administered an inhaled formulation of glutathione (600 mg twice daily for 3 days) to 10 patients with IPF and 19 healthy non-smokers as controls for 3 days. The results showed that inhaled therapy of IPF with glutathione was well tolerated and had biologic efficacy because it interacted favourably with both intracellular and extracellular events, resulting in a net reduction in the oxidant burden at the alveolar epithelial surface.

\subsubsection{Cystic Fibrosis}

In patients with CF, Tam et al. [44], in their review on the use of thiol derivates such as NAC, reported that nebulized thiol derivatives were generally well tolerated.

\section{Conclusion}

Studies of high doses of NAC (up to $3000 \mathrm{mg} /$ day) in respiratory diseases with explicit reports on safety found that NAC was safe and well tolerated. In general, the safety profile is similar at both the high and standard doses.

Gastrointestinal symptoms were reported when NAC was administered orally; however, in most of the studies, the gastrointestinal symptoms were not more common than in the control group. Cough with inhaled NAC was also common but did not prevent patients from continuing the treatment. NAC alone or in combination therapy has been found to be well tolerated in chronic bronchitis, COPD and CF. However, attention should be paid in cases of IPF; a three-drug regimen (prednisone, azathioprine and NAC) potentially increased the rate of deaths [37] and cardiac disorders when 
used at a dose of $1800 \mathrm{mg} /$ day in these patients [38]. Why this should be the case remains unclear.

Fewer studies have explored inhaled formulations, but similar safety profiles were reported. This remains a promising route for the delivery of higher doses of this versatile drug directly to the lungs. Future clinical trials can be conducted in diseases such as COPD and CF with the confidence that a range of oral doses of NAC are both well tolerated and safe for chronic use in these diseases.

Acknowledgements Medical writing support provided by EDRA SpA was utilized in the preparation of this paper and was funded by Zambon.

Funding Open access funding provided by Università degli Studi di Ferrara within the CRUI-CARE Agreement.

\section{Declarations}

Funding Not applicable

Conflict of interest Peter Calverley has received consulting and personal fees from AstraZeneca, Boehringer Ingelheim GmbH, GlaxoSmithKline, Regeneron Sanofi, Recipharm, Philips Medical and Zambon Company SpA, who sponsored this analysis. Paola Rogliani participated as a lecturer, speaker, and advisor for Almirall, AstraZeneca, Biofutura, Boehringer Ingelheim, Chiesi Farmaceutici, GlaxoSmithKline, Menarini Group, Mundipharma, and Novartis. Her department was funded by Almirall, Boehringer Ingelheim, Novartis, Zambon and Chiesi Farmaceutici. Alberto Papi reports grants, personal fees, and/or reimbursement of travel expenses from AstraZeneca, Chiesi, Boehringer Ingelheim, GlaxoSmithKline, Menarini, Merck Sharp \& Dohme, Mundipharma, Novartis, Teva, Sanofi, and Zambon.

Ethics approval Not applicable.

Consent to participate Not applicable.

Consent for publication Not applicable.

Availability of data and material Not applicable.

Code availability Not applicable.

Authors contributions All authors contributed to the review conception and design, and revised and commented on all versions of the manuscript. All authors read and approved the final manuscript.

Open Access This article is licensed under a Creative Commons Attribution-NonCommercial 4.0 International License, which permits any non-commercial use, sharing, adaptation, distribution and reproduction in any medium or format, as long as you give appropriate credit to the original author(s) and the source, provide a link to the Creative Commons licence, and indicate if changes were made. The images or other third party material in this article are included in the article's Creative Commons licence, unless indicated otherwise in a credit line to the material. If material is not included in the article's Creative Commons licence and your intended use is not permitted by statutory regulation or exceeds the permitted use, you will need to obtain permission directly from the copyright holder. To view a copy of this licence, visit http://creativecommons.org/licenses/by-nc/4.0/.

\section{References}

1. Grant JE, Odlaug BL, Chamberlain SR, Potenza MN, Schreiber LR, Donahue CB, Kim SW. A randomized, placebo-controlled trial of $N$-acetylcysteine plus imaginal desensitization for nicotine-dependent pathological gamblers. J Clin Psychiatry. 2014;75:39-45.

2. Kay J, Chow WH, Chan TM, Lo SK, Kwok OH, Yip A, et al. $\mathrm{N}$-Acetylcysteine for prevention of acute deterioration of renal function following elective coronary angiography and in intervention: a randomized controlled trial. J Am Med Assoc. 2003;41:2114-8.

3. Miner SE, Dzavik V, Nguyen-Ho P, Richardson R, Mitchell J, Atchison $\mathrm{D}$, et al. $\mathrm{N}$-Acetylcysteine reduces contrast-associated nephropathy but not clinical events during long-term follow-up. Am Heart J. 2004;148:690-5.

4. Ooi SL, Green R, Pak SC. N-Acetylcysteine for the treatment of psychiatric disorders: a review of current evidence. Biomed Res Int. 2018;2018:2469486.

5. Tardiolo G, Bramanti P, Mazzon E. Overview on the effects of $\mathrm{N}$-acetylcysteine in neurodegenerative diseases. Molecules. 2018;23:3305. https://doi.org/10.3390/molecules23123305.

6. Makin AJ, Wendon J, William RA. A 7 year experience of severe acetaminophen-induced hepatotoxicity (1987-1993). Gastroenterology. 1995;109:1907-16.

7. Smilkstein MJ, Knapp GL, Kulig KW, Rumack BH. Efficacy of oral $\mathrm{N}$-acetylcysteine in the treatment of acetaminophen overdose: analysis of the National Multicenter Study (1976-1985). N Engl J Med. 1988;319:1557-62.

8. Habib M, Hillis A, Hammad A. N-Acetylcysteine and/or ascorbic acid versus placebo to prevent contrast-induced nephropathy in patients undergoing elective cardiac catheterization: the NAPCIN trial; a single-center, prospective, randomized trial. Saudi J Kidney Dis Transpl. 2016;27:55-61.

9. Baker CS, Wragg A, Kumar S, De Palma R, Baker LR, Knight CJ. A rapid protocol for the prevention of contrast-induced renal dysfunction: the RAPPID study. J Am CollCardiol. 2003;41:2114-8.

10. Briguori C, Colombo A, Violante A, Balestrieri P, Manganelli F, Paolo Elia P, et al. Standard vs double dose of $N$-acetylcysteine to prevent contrast agent associated nephrotoxicity. Eur Heart J. 2004;25:206-11.

11. Global Strategy for the Diagnosis, Management and Prevention of COPD, Global Initiative for Chronic Obstructive Lung Disease (GOLD) 2017. https://goldcopd.org.

12. Barratt SL, Creamer A, Hayton C, Chaudhuri N. Idiopathic pulmonary fibrosis (IPF): an overview. J Clin Med. 2018;7:201. https ://doi.org/10.3390/jcm7080201.

13. Stey $\mathrm{C}$, Steurer J, Bachmann $\mathrm{S}$, Medici TC, Tramèr MR. The effect of oral $N$-acetylcysteine in chronic bronchitis: a quantitative systematic review. EurRespir J. 2000;16:253-62.

14. Grandjean EM, Berthet P, Ruffmann R, Leuenberger P. Efficacy of oral long-term $N$-acetylcysteine in chronic bronchopulmonary disease: a meta-analysis of published double-blind, placebo-controlled clinical trials. ClinTher. 2000;22:209-21.

15. Pela R, Calcagni AM, Subiaco S, Isidori P, Tubaldi A, Sanguinetti CM. $N$-Acetylcysteine reduces the exacerbation rate in patients with moderate to severe COPD. Respiration. 1999;66:495-500.

16. Kasielski M, Nowak D. Long-term administration of $N$-acetylcysteine decreases hydrogen peroxide exhalation in subjects with chronic obstructive pulmonary disease. Respir Med. 2001;95:448-56.

17. Nowak D, Carati L, Pirozynski M. Long-term administration of $\mathrm{N}$-acetylcysteine reduces the number of acute exacerbation episodes in subjects with chronic obstructive pulmonary diseases. Report of the BREATHE study. EurRespir J. 1999;14:381-2. 
18. Decramer M, Rutten-van Mölken M, Dekhuijzen PN, Troosters T, van Herwaarden C, Pellegrino R, et al. Effects of $N$-acetylcysteine on outcomes in chronic obstructive pulmonary disease (Bronchitis randomized on NAC cost-utility study, BRONCUS): a randomized placebo-controlled trial. Lancet. 2005;365:1552-60.

19. Cazzola M, Calzetta L, Page C, Jardim J, Chuchalin AG, Rogliani $\mathrm{P}$, Matera MG. Influence of $\mathrm{N}$-acetylcysteine on chronic bronchitis or COPD exacerbations: a meta-analysis. EurRespir Rev. 2015;24:451-61.

20. Hansen NC, Skriver A, Brorsen-Riis L, Balsløv S, Evald T, Maltbaek N, et al. Orally administered $N$-acetylcysteine may improve general well-being in patients with mild chronic bronchitis. Respir Med. 1994;88:531-5.

21. Zheng JP, Wen FQ, Bai CX, Wan HY, Kang J, Chen P, PANTHEON study group, et al. Twice daily $N$-acetylcysteine $600 \mathrm{mg}$ for exacerbations of chronic obstructive pulmonary disease (PANTHEON): a randomized, double-blind placebo-controlled trial. Lancet Respir Med. 2014;2:187-94.

22. Tse HN, Raiteri L, Wong KY, Yee KS, Ng LY, Wai KY, et al. High-dose $N$-acetylcysteine in stable COPD: the 1-year, doubleblind, randomized, placebo-controlled HIACE study. Chest. 2013;144:106-18.

23. Tse HN, Raiteri L, Wong KY, Ng LY, Yee KS, Tseng CZ. Benefits of high-dose $N$-acetylcysteine to exacerbation-prone patients with COPD. Chest. 2014;146:611-23.

24. Stav D, Raz M. Effect of $N$-acetylcysteine on air trapping in COPD: a randomized placebo-controlled study. Chest. 2009; 136:381-6.

25. Black PN, Morgan-Day A, McMillan TE, Poole PJ, Young RP. Randomized, controlled trial of $\mathrm{N}$-acetylcysteine for treatment of acute exacerbations of chronic obstructive pulmonary disease ISRCTN21676344. BMC Pulm Med. 2004;4:13.

26. Zhang JQ, Zhang JQ, Fang LZ, Liu L, Fu WP, Dai LM. Effect of oral $N$-acetylcysteine on COPD patients with microsatellite polymorphism in the heme oxygenase-1 gene promoter. Drug Des DevelTher. 2015;9:6379-87.

27. Rogliani P, Matera MG, Page C, Puxeddu E, Cazzola M, Calzetta L. Efficacy and safety profile of mucolytic/antioxidant agents in chronic obstructive pulmonary disease: a comparative analysis across erdosteine, carbocysteine, and $\mathrm{N}$-acetylcysteine. Respir Res. 2019;20:104.

28. Qi Q, Ailiyaer Y, Liu R, Zhang Y, Li C, Liu M, et al. Effect of $\mathrm{N}$-acetylcysteine on exacerbations of bronchiectasis (BENE): a randomized controlled trial. Respir Res. 2019;20:73.

29. Hirai DM, Jones JH, Zelt JT, da Silva ML, Bentley RF, Edgett BA, et al. Oral $N$-acetylcysteine and exercise tolerance in mild chronic obstructive pulmonary disease. J ApplPhysiol. 1985;2017(122):1351-61.

30. Johnson K, McEvoy CE, Naqvi S, Wendt C, Reilkoff RA, Kunisaki KM, et al. High-dose oral $N$-acetylcysteine fails to improve respiratory health status in patients with chronic obstructive pulmonary disease and chronic bronchitis: a randomized, placebocontrolled trial. Int J ChronObstrPulm Dis. 2016;11:799-807.

31. Sayin VI, Ibrahim MX, Larsson E, Nilsson JA, Lindahl P, Bergo MO. Antioxidants accelerate lung cancer progression in mice. SciTransl Med. 2014;6:221ra15.

32. De Backer LA, Vos W, De Backer J, Van Holsbeke C, Vinchurkar $\mathrm{S}$, De Backer W. The acute effect of budesonide/formoterol in COPD: a multi-slice computed tomography and lung function study. EurRespir J. 2012;40:298-305.

33. De Backer J, Vos W, Van Holsbeke C, Vinchurkar S, Claes R, Parizel PM, et al. Effect of high-dose $N$-acetylcysteine on airway geometry, inflammation, and oxidative stress in COPD patients. Int J ChronObstrPulm Dis. 2013;8:569-79.

34. Bridgeman MM, Marsden M, Selby C, Morrison D, MacNee W. Effect of $\mathrm{N}$-acetyl cysteine on the concentrations of thiols in plasma, bronchoalveolar lavage fluid, and lung tissue. Thorax. 1994;49:670-5.

35. Behr J, Maier K, Degenkolb B, Krombach F, Vogelmeier C. Antioxidative and clinical effects of high-dose $N$-acetylcysteine in fibrosingalveolitis: adjunctive therapy to maintenance immunosuppression. Am J RespirCrit Care Med. 1997;156:1897-901.

36. Demedts M, Behr J, Buhl R, Costabel U, Dekhuijzen R, Jansen HM, IFIGENIA Study Group, et al. High-dose acetylcysteine in idiopathic pulmonary fibrosis. N Engl J Med. 2005;353:2229-42.

37. Idiopathic Pulmonary Fibrosis Clinical Research Network, Raghu G, Anstrom KJ, King TE Jr, Lasky JA, Martinez FJ. Prednisone, azathioprine, and $N$-acetylcysteine for pulmonary fibrosis. N Engl J Med. 2012;366:1968-77.

38. Idiopathic Pulmonary Fibrosis Clinical Research Network, Martinez FJ, de Andrade JA, Anstrom KJ, King TE Jr, Raghu G. Randomized trial of acetylcysteine in idiopathic pulmonary fibrosis. N Engl J Med. 2014;370:2093-101.

39. Oldham JM, Ma SF, Martinez FJ, Anstrom KJ, Raghu G, Schwartz DA, IPFnet Investigators, et al. TOLLIP, MUC5B, and the response to $\mathrm{N}$-acetylcysteine among individuals with idiopathic pulmonary fibrosis. Am J RespirCrit Care Med. 2015;192:1475-82.

40. Huang H, Dai HP, Kang J, Chen BY, Sun TY, Xu ZJ. Double-blind randomized trial of pirfenidone in Chinese idiopathic pulmonary fibrosis patients. Medicine (Baltimore). 2015;94:e1600.

41. Behr J, Bendstrup E, Crestani B, Günther A, Olschewski H, Sköld $\mathrm{CM}$, et al. Safety and tolerability of acetylcysteine and pirfenidone combination therapy in idiopathic pulmonary fibrosis: a randomized, double-blind, placebo-controlled, phase 2 trial. Lancet Respir Med. 2016;4:445-53.

42. Ventresca GP, Cicchetti V, Ferrari V. Thiols. In: Braga PC, Allegra L, editors. Drugs in bronchial mucology. New York: Raven Press; 1989. p. 77-102.

43. Adler KB, Hendley DD, Davis GS. Bacteria associated with obstructive pulmonary disease elaborate extracellular products that stimulate mucin secretion by explants of guinea pig airways. Am J Pathol. 1986;125:501-14.

44. Tam J, Nash EF, Ratjen F, Tullis E, Stephenson A. Nebulized and oral thiol derivatives for pulmonary disease in cystic fibrosis. Cochrane Database Syst Rev. 2013;7:CD007168.

45. Conrad C, Lymp J, Thompson V, Dunn C, Davies Z, Chatfield B, et al. Long-term treatment with oral $N$-acetylcysteine: affects lung function but not sputum inflammation in cystic fibrosis subjects. A phase II randomized placebo-controlled trial. J Cyst Fibros. 2015;14:219-27.

46. Skov M, Pressler T, Lykkesfeldt J, Poulsen HE, Jensen PØ, Johansen HK, et al. The effect of short-term, high-dose oral $\mathrm{N}$-acetylcysteine treatment on oxidative stress markers in cystic fibrosis patients with chronic $P$. aeruginosa infection: a pilot study. J Cyst Fibros. 2015;14:211-8.

47. Tirouvanziam R, Conrad CK, Bottiglieri T, Herzenberg LA, Moss RB, Herzenberg LA. High-dose oral $N$-acetylcysteine, a glutathione prodrug, modulates inflammation in cystic fibrosis. ProcNatlAcadSci USA. 2006;103:4628-33.

48. Meyer A, Buhl R, Kampf S, Magnussen H. Intravenous $N$-acetylcysteine and lung glutathione of patients with pulmonary fibrosis and normals. Am J RespirCrit Care Med. 1995;152:1055-60.

49. Homma S, Azuma A, Taniguchi H, Ogura T, Mochiduki Y, Sugiyama Y, Japan NAC Clinical Study Group, et al. Efficacy of inhaled $N$-acetylcysteine monotherapy in patients with early stage idiopathic pulmonary fibrosis. Respirology. 2012;17:467-77.

50. Okuda R, Matsushima H, Aoshiba K, Oba T, Kawabe R, Honda $\mathrm{K}$, et al. Soluble intercellular adhesion molecule- 1 for stable and acute phases of idiopathic pulmonary fibrosis. Springerplus. 2015;4:657. 
51. Muramatsu Y, Sugino K, Ishida F, Tatebe J, Morita T, Homma S. Effect of inhaled $N$-acetylcysteine monotherapy on lung function and redox balance in idiopathic pulmonary fibrosis. RespirInvestig. 2016;54:170-8.

52. Sakamoto S, Muramatsu Y, Satoh K, Ishida F, Kikuchi N, Sano $\mathrm{G}$, et al. Effectiveness of combined therapy with pirfenidone and inhaled $N$-acetylcysteine for advanced idiopathic pulmonary fibrosis: a case-control study. Respirology. 2015;20:445-52.
53. Borok Z, Buhl R, Grimes GJ, Bokser AD, Hubbard RC, Holroyd $\mathrm{KJ}$, et al. Effect of glutathione aerosol on oxidant-antioxidant imbalance in idiopathic pulmonary fibrosis. Lancet. 1991;338:215-6. 